\title{
OPEN INNOVATIONS AS A FORM OF CUSTOMER VALUE CO-CREATION
}

OTWARTE INNOWACJE JAKO FORMA WSPÓŁTWORZENIA WARTOŚCI PRZEZ KLIENTÓW

\section{Krystyna Mazurek-Łopacińska, Professor}

The Wroclaw University of Economics and Business

53-345 Wroclaw, ul. Komandorska 118/120, bud. B, Poland

krystyna.m.lopacinska @gmail.com • ORCID 0000-0002-0034-8344

DOl: 10.2478/minib-2021-0005

\section{ABSTRACT}

The article aims to present customer participation in value co-creation based on the demand-side approach to innovation. We present the rationale and principles of the demand-side approach to innovation based on user participation. Further, we discuss the forms of customer engagement in customer-company cooperation, customer motivations, and perceived benefits. This article also identifies the open innovation model's factors and provides practitioners with implementation guidance regarding the demand approach to innovation. Further, this article shows the influence of the customer's active role and the demand-side approach to innovation on the enterprise, the economy, and society. Finally, we identify possible risks associated with using this approach and their impact on the environment.

Key words: COM, co-creation, open innovations, customer, factors, user participation, cooperation 


\section{ABSTRAKT}

Przedmiotem artykułu jest przedstawienie różnych aspektów udziału klientów w procesie współtworzenia wartości opartego na popytowym podejściu do innowacji. Wskazano na przesłanki i zasady popytowego podejścia do innowacji opartego na uczestnictwie użytkowników. Omówiono formy zaangażowania i uczestnictwa klientów we współpracy z firmą, ich motywacje i postrzegane korzyści. Wskazano na czynniki kształtujące proces wdrażania modelu open innovation oraz kierunki zmian w zarządzaniu przedsiębiorstwem sprzyjające wdrażaniu popytowego podejścia do innowacji. Na koniec przedstawione zostały kierunki oddziaływania aktywnej roli klienta i popytowego podejścia do innowacji na przedsiębiorstwo, gospodarkę i społeczeństwo. Podkreślono także możliwe zagrożenia związane ze stosowaniem tego podejścia w zarządzaniu przedsiębiorstwem i w oddziaływaniu na otoczenie.

Słowa kluczowe: współtworzenie, otwarte innowacje, klient, czynniki, udział użytkowników, współpraca

JEL: D 12, M 31, 033, 034, 035

\section{Introduction}

Innovation in organizations has become a challenge for modern economies and a condition for keeping up with changes in the environment and shaping these changes in societies, social groups, and individuals. A broad understanding of innovation is to see beyond the achievements of researchers, experts, science, and technology. Innovation also includes the contributions from customers who are the ultimate users of goods and services. Thanks to their knowledge, skills, experiences, different points of view, and needs, they become active participants in the innovation process. Indeed, companies have recently begun to understand that the customers' 
intellectual capital can be a strategic set of intangible assets that influence competitive advantage (Rossi, Magni, 2017).

Creating innovation from the customer's perspective is a way to invest in customers and to increase their value for the company (DobiegałaKorona 2010). The benefits for both parties depend on the innovation model. Models presented in the literature differ based on the customer's participation in the innovation process. Some models are based only on customer opinions ("voice of the customer"), and other models are based on the customers' active participation. The authors indicate what motivates customers to participate in the co-creation of value and the requirements for increasing the effectiveness of these forms of cooperation. Further, we suggest the directions of changes that would help increase the chances of achieving the company's desired effects (see also Mierzejewska, 2008; Wojnicka, 2011; Baran, Ostrowska, Pander, 2012; Busse, Siebert, 2018).

Using an agent-based approach, Ohori and Takahashi (2007) have created a model for analyzing innovation generated by the leading users. The conducted simulations showed that companies could effectively manage innovations with the leading users' participation if only they change their strategy by focusing on innovation communities.

Empirical studies conducted among Polish enterprises on user-created innovation indicate the limitations and benefits of applying such a concept in business practice. This can help researchers develop theories concerning other open innovation forms (Szopik-Depczyńska, 2018). An important direction of this research is related to the factors that hinder customers from submitting their ideas (Chepurna, Criado, 2018; Balaji, Roy, 2017; Gummesson, Mele, 2010), as the ability to overcome these barriers determines the level of activity and involvement of users in the innovation process.

The purpose of the article is to present factors affecting the process of co-creation of value with the participation of customers, with particular emphasis on open innovation. Further, this article indicates companycustomer cooperation conditions and the positive and negative effects of the demand-driven approach to innovation. 


\section{Rationale and principles of the demand-side approach to innovation based on user participation}

The mechanism of open innovation is based on the idea of the free flow of knowledge, ideas, and technologies essential for creating innovation. Engaging the company's stakeholders, especially customers, affects innovation policy changes and the company's business model. The development of open innovation brings evident benefits to the company. Those benefits are recognized not only by technology start-ups but also by companies from other industries. However, achieving these benefits requires appropriate management of the innovation process, reformulation of its objectives, principles, and instruments.

First of all, it is crucial to identify customers ready to cooperate with the company and determine the terms and conditions of this cooperation. However, the question arises: how do we identify such customers? Based on observations of behavior and relations with customers, the following groups are the most susceptible to cooperation with the company in generating innovation:

- Loyal customers of the brand, interested in its development and willing to cooperate with the company and the brand

- Demanding, active customers who expect personalization of the offer, its adaptation to individual expectations

- Influencers whose susceptibility to cooperation with a company is motivated by the desire to influence other users of the product, e.g., followers

- Institutional customers interested in cooperation with a company as it allows them to achieve mutual business benefits

The forms of stimulating involvement in creating innovations depend on the type of customers, and especially on whether they are individual or institutional customers.

There are several principles of a demand-driven approach to innovation that is based on user participation. Based on the literature review and the experience from the project "U — Drive: IT — User-Driven Innovation Transfer From ICT to Other Sectors, conducted within the Nordic 
Innovation Center, we emphasize that in the era of network intelligence, we state that the following principles are particularly crucial:

a) Sharing knowledge - getting ideas from users

b) Cooperating with the participants in the process of creating innovations

c) Openness to ideas, opinions, and comments of other participants of the innovation process

d) Using experience - the design process should be powered by applying previous experience, improving the existing solutions, and implementing new ideas. Simulations are also necessary, e.g., using 3D visualizations or simulation computer games

e) Interdependence - acknowledging mutual relations between participants of the innovation process

f) Honesty - transferring transparent information, opinions, results obtained at particular stages of the innovation process

g) Contextualisation - participatory design depends on the specific context in which it takes place. Participants (users, inventors, or producers) in the innovation process have different objectives and motivations which need to be recognized for the benefit of the process improvement

h) Iteration - active participation of users in the innovation process is revealed in generating ideas and creating prototypes that users evaluate. The proper improvement of the prototype and its iteration affects the desired final result (Tapscott, Williams, 2011, p. 32, Nordic Report, 2010, p. 21).

According to H.Chesbrough, who first pointed to Open Innovation as a concept of using internal and external ideas in creating innovation, it is cocreated by the following elements:

1. Network.

2. Collaboration involving partners, competitors, universities, and users.

3. Corporate entrepreneurship, especially through corporate ventures, start-ups, and spin-offs.

4. Proactive management of intellectual property: buying and selling intellectual property and thus creating technology markets. 
5. Research and development (R\&D) to gain a competitive advantage in the marketplace (Chesbrough, 2003).

Table 1 shows three models of customer involvement in the innovation process depending on whether the customers are merely a source of information, whether they co-create the innovation in collaboration with the company, or, finally, whether a customer is an innovator who owns their intellectual property.

\section{Table 1. The customers' role in creating innovation in cooperation with the company}

\begin{tabular}{l|l|l|l}
\hline Specification & $\begin{array}{l}\text { Customer as a source } \\
\text { of information }\end{array}$ & $\begin{array}{l}\text { Customer as a co-creator } \\
\text { of new products }\end{array}$ & Customer as innovator \\
\hline Customers' role & $\begin{array}{l}\text { Customers play a passive } \\
\text { role as information providers }\end{array}$ & $\begin{array}{l}\text { Customers are co-creators } \\
\text { of new products }\end{array}$ & $\begin{array}{l}\text { Customers design new } \\
\text { products themselves }\end{array}$ \\
\hline Company's role & $\begin{array}{l}\text { The company is responsible } \\
\text { for developing product } \\
\text { solutions }\end{array}$ & $\begin{array}{l}\text { The company manage } \\
\text { cooperation with customers } \\
\text { in the field of product } \\
\text { development }\end{array}$ & $\begin{array}{l}\text { The company provides } \\
\text { technical expertise and supports } \\
\text { customers. The company uses } \\
\text { customer-generated product } \\
\text { designs }\end{array}$ \\
\hline Specific techniques & $\begin{array}{l}\text { Traditional marketing } \\
\text { research techniques; } \\
\text { Concept and product testing }\end{array}$ & $\begin{array}{l}\text { Lead user method; } \\
\text { Joint development projects } \\
\text { in the B-B-B context }\end{array}$ & $\begin{array}{l}\text { User toolkits; User community } \\
\text { innovation/design }\end{array}$ \\
\hline Conditions & $\begin{array}{l}\text { Development of infrastructure } \\
\text { for research and conditions } \\
\text { for obtaining information } \\
\text { from customers in the } \\
\text { process of creating innovations }\end{array}$ & $\begin{array}{l}\text { Company changes to develop } \\
\text { relationships with leaders } \\
\text { to cooperate on new } \\
\text { solutions }\end{array}$ & $\begin{array}{l}\text { Changes in company } \\
\text { structure, processes, } \\
\text { and cultural norms conducive } \\
\text { to encouraging and valuing } \\
\text { innovator activity }\end{array}$ \\
\hline
\end{tabular}

Source: Based on Cui A, (2018) and Mazurek-Łopacińska (2012, 2013).

There is no doubt that electronic communication is crucial in creating innovation. The interactive nature of such communication encourages users to interact with the company and with other users. They become more active and strive to take advantage of the opportunities. By proposing 
new products, customers express themselves and their needs and aspirations. ICT-based solutions help create platforms through which users can submit their ideas for a new product and evaluate other products. On the other hand, the company can get acquainted with them and choose the most promising idea.

In summary, the development of demand-side innovation requires stimulating the customers' interest and willingness to cooperate with the company and creating the conditions for such cooperation. It brings benefits to both the company and the customer, which is translated into benefits for the economy and society.

\section{Forms of consumer activity in open innovation}

The forms of stimulating involvement in creating innovations depend on the type of customer and methods of obtaining ideas and creative solutions. Suppose the company uses only one-way communication (e.g., through ideas submitted on Internet forums or under models based on mass customization or task-based models). In that case, the complexity of such a process is low (Sopinska, 2013). More complex solutions include twoway communication, in which a company uses participation platforms and models based on the open-source. In such a case, the partnership with users who have access to software tools and databases expands their creative opportunities. The effects of these more complex solutions depend on the proper preparation of project assumptions, access to software tools and databases, and users' competence in creating new solutions. Managersexperts of crowdsourcing are critical in this process, as they evaluate submitted ideas, identify high-quality ideas, and incorporate them into the internal research and development process (Liu, Zhao, Sun, 2018).

There are many examples of companies implementing successfully open-source innovation programs. They include P\&G, IBM, InnoCentive, Unilever, Mars, SAP, Kellogg's, Mondelez International (Kraft Foods), Vodafone. Achieving success requires developing a strategy of action and effective forms of cooperation to create new value. It is also necessary to use a specific platform for the realization 
of this cooperation. Among such platforms are platforms based on the design and exchange of ideas, platforms for creative co-creation of products, corporate initiatives - product ideas, corporate initiativesbranding and design, partner production and $\mathrm{PiP}$, public crowdsourcing (Szopik-Depczyńska, 2018, p. 105).

\section{Table 2. Forms of customer activity in open innovation}

\begin{tabular}{|c|c|c|c|}
\hline Forms & Goals & Challenges and problems & Scope, use cases \\
\hline Competitions & $\begin{array}{l}\text { Generate valuable ideas } \\
\text { to solve complex } \\
\text { or new problems }\end{array}$ & $\begin{array}{l}\text { The problem should be } \\
\text { formulated in a general } \\
\text { way, i.e., without reference } \\
\text { to specific aspects of } \\
\text { a particular company }\end{array}$ & $\begin{array}{l}\text { Complex, challenging } \\
\text { technical, analytical, } \\
\text { and scientific problems, } \\
\text { as well as aesthetics ones }\end{array}$ \\
\hline $\begin{array}{l}\text { Collaborative } \\
\text { communities }\end{array}$ & $\begin{array}{l}\text { Aggregating, a large number } \\
\text { of different views expressed } \\
\text { by community members } \\
\text { to co-create value }\end{array}$ & $\begin{array}{l}\text { A crowd, unlike a company, } \\
\text { lacks a common culture } \\
\text { and cohesion, making } \\
\text { it difficult to control its } \\
\text { functioning and protect } \\
\text { its intellectual property }\end{array}$ & $\begin{array}{l}\text { Customer support } \\
\text { communities; open forms } \\
\text { of collaboration enable } \\
\text { information and software } \\
\text { (software products) to be } \\
\text { combined with } \\
\text { complementary internal } \\
\text { company resources }\end{array}$ \\
\hline $\begin{array}{l}\text { Complementors } \\
\text { communities }\end{array}$ & $\begin{array}{l}\text { Encouraging users } \\
\text { associated with the core } \\
\text { product to innovate solutions } \\
\text { to a wide variety of product } \\
\text { management problems }\end{array}$ & $\begin{array}{l}\text { The need to provide } \\
\text { external partners with } \\
\text { access to features and } \\
\text { information about the } \\
\text { core product, which may } \\
\text { discourage a company } \\
\text { that is sensitive to } \\
\text { protecting its assets }\end{array}$ & $\begin{array}{l}\text { Open initiatives on } \\
\text { operational, product, } \\
\text { or marketing issues }\end{array}$ \\
\hline Gamification & $\begin{array}{l}\text { Integrating customers } \\
\text { with the company to } \\
\text { learn about its problems, } \\
\text { stimulate creativity and } \\
\text { generate new ideas }\end{array}$ & $\begin{array}{l}\text { Stimulating motivation } \\
\text { and understanding } \\
\text { of company problems and } \\
\text { overcome unpredictable } \\
\text { situations }\end{array}$ & $\begin{array}{l}\text { The used application puts } \\
\text { the user at the center of the } \\
\text { game for developing } \\
\text { a sense of equality } \\
\text { of partners in the company, } \\
\text { formulating common goals } \\
\text { and decisions }\end{array}$ \\
\hline
\end{tabular}

Source: own elaboration based on Boudreau and Lakhani, 2013, Robra-Bissantz, Lattemann, 2017. 
A good example is the Bright Idea platform which gathers thousands of ideas that allow solving complex problems that R\&D departments of the largest corporations such as Cisco, GE, MasterCard cannot cope with. Kaggle platform, on the other hand, offers access to the computing power of thousands of data analysts, which generates more agility than any artificial intelligence (Malinowski, 2018). ICT-based innovations are important in studying the demand-side approach to innovation because they are based on the cooperation between a supplier and customer in all stages of product creation and sales.

Von Hippel (2015) indicated that the trend towards democratization of innovation is growing through software and information products. However, recently, also other products and services such as surgical equipment, surfboards, and software security have become important in this process. Such trend is enforced by so-called "leading users" who are often ahead of market trends. They propose innovative and attractive solutions to users, which translates into the company's success.

Table 2 presents the primary forms of implementing open innovation, indicating objectives, challenges, and situations in which they are applied.

\section{Competitions as a form of creating innovations with customer participation}

The most popular and effective form used in open innovation models is competitions. Competitions allow expanding the experimentation scope by soliciting proposals for multiple solutions from external participants (amateurs or specialists). This is especially important when the problem is complex or novel.

The broad development of crowdsourcing platforms facilitates individual users' creative potential to generate new product, organizational, and marketing solutions.

As shown in Table 2, running an open innovation competition involves significant management challenges. First of all, it is necessary to formulate the problem regardless of company-specific qualities and present it to be entirely understandable for many external partners interested in 
participating in the competition. This may require breaking it down into many sub-problems or even different competitions.

The contest's assumptions and structure should stimulate customers to participate by bringing solutions that the organization can implement. Moreover, promoting the contest is very important, including a clear presentation of the evaluation rules of solutions, expected prizes, or other forms of recognition for the participants.

The company should also define the contractual terms of participation, including the platform's use, to ensure proper intellectual property protection. An excellent way to do this is to use prior agreements to respect copyrights and conforming behavior to the rules and the brief.

It is also necessary to pay attention to the need to use various forms of support for participants, i.e., dispelling their doubts, answering their questions, e.g., by conducting chats during the project and the possibility to contact the crowd manager responsible for coordinating the contest (Milewski, 2015).

Companies can use various online platforms designed to run contests for customers and other external entities. Currently, platforms such as TopCoder, Kaggle, and InnoCentive provide services for crowd contests. Those platforms facilitate participants' engagement in such contests and streamline acquiring ideas in the co-creation of innovations. They also enable to process of payments, secure data, and transfer of intellectual property rights worldwide (Boudreau and Lakhani, 2013).

A good example of a software platform used in the open innovation model is CRM-Salesforce's "Ideas," where users submit their suggestions, which other customers comment on, allowing further idea analysis and evaluation. This platform is used by Starbucks and DELL, among others, and has been successfully used to improve those companies' products and other offers.

Customers are the leading creators and evaluators of ideas, which the organization's teams further implement. Starbucks managers found that the process of innovation's creation requires an understanding of incentives that drive people who participate in creating ideas. It turns out that satisfaction and pride in participating in co-design can be an important motivator for customers cooperating with the brand (Starbucks, 2020). Such a trend is confirmed by the Lakhani and Wolf's (2003) study 
conducted on a sample of 684 programmers. Their study showed that the main motivating factors for participating in open-source software projects come from the user's intrinsic needs, the desire for intellectual stimulation associated with writing code, and improving programming skills (Lakhani and Wolf, 2003 ).

\section{The role of collaborative communities}

In the era of network intelligence, an important role in stimulating customer involvement in generating innovation is played by Online Communities created by people interested in a particular idea, brand, or activity type. The high rate of interaction between members of such communities increases their effectiveness in creating new solutions.

As a result, many social platforms now offer projects tailored to the community's life, stimulating engagement in the creation of ideas for new products. Examples of such inspirations include Unilever's sustainability products under the Unilever Sustainable Living Plan or the self-driving city buses, i.e., Accessible Olli produced by Local Motors. As part of crowdsourcing, customers can also co-determine whether a project qualifies for implementation, e.g., a new collection of yoga clothing by the British brand Catalyst Activewear. Starbucks has implemented many customersubmitted ideas. They include new products (such as Skinny Mocha, Cake Pops, sugar-free syrups, K cups), creating experiences (free Wi-Fi in their coffee shops), and ways to build community (Norton, 2019).

The strength of communities is their diversity. They can attract participants from all over the world - from different companies, domains, and industries - who have their interests and motivations, which fosters inspiration. Further, there are possibilities of shaping high consumer engagement by stimulating fan pages in social media, blogs, marketing games, and crowdsourcing platforms. Such activities' high effectiveness has been observed, especially in the high-tech goods and banking sectors (Kieżel, Wiechoczek, 2016). What is noted is the potential of brand fans whose involvement is conducive to encouraging the promotion of ideas and innovation projects in their communities. One weakness of communities is the lack of cohesion, which makes it difficult to control crowds. 
Tab. 3 presents examples of using online communities' potential in value creation, highlighting the benefits of such forms of cooperation.

Table 3. Examples of co-creation of values by internet communities

\begin{tabular}{|c|c|c|c|}
\hline Company & Platform & Community & Benefits \\
\hline Google & $\begin{array}{l}\text { Android - an open platform } \\
\text { for developing applications } \\
\text { for wireless devices }\end{array}$ & $\begin{array}{l}\text { Global internet } \\
\text { community }\end{array}$ & $\begin{array}{l}\text { The emergence of an } \\
\text { open market for mobile } \\
\text { device applications for } \\
\text { users and developers }\end{array}$ \\
\hline Colgate-Palmolive & $\begin{array}{l}\text { Colgate-Palmolive's open } \\
\text { innovation submission } \\
\text { portal.yet2 }\end{array}$ & $\begin{array}{l}\text { Cooperation with the } \\
\text { "Tongal community" }\end{array}$ & $\begin{array}{l}\text { Developed Speed Stick's } \\
\text { "Handle It" campaign } \\
\text { ads for the Super Bowl, } \\
\text { distancing ads by Calvin Klein, } \\
\text { Volkswagen, Coca-Cola, } \\
\text { Toyota, and Pepsi }\end{array}$ \\
\hline Bank Zachodni WBK & $\begin{array}{l}\text { An online platform } \\
\text { called the Idea Bank }\end{array}$ & $\begin{array}{l}\text { The community of } \\
\text { internet users who use } \\
\text { banking services }\end{array}$ & $\begin{array}{l}\text { Offer development and } \\
\text { improvement Creating } \\
\text { an image of an engaged and } \\
\text { customer-friendly brand }\end{array}$ \\
\hline IBM & Crowdsourcing platform & $\begin{array}{l}\text { Appache - the } \\
\text { online community } \\
\text { for webmasters } \\
\text { and technologists }\end{array}$ & $\begin{array}{l}\text { Collaborative development } \\
\text { of new computer programs }\end{array}$ \\
\hline Lego & Lego Platform & $\begin{array}{l}\text { The community } \\
\text { of brand fans }\end{array}$ & $\begin{array}{l}\text { Inventing designs } \\
\text { for new toys }\end{array}$ \\
\hline $\begin{array}{l}\text { IDEO, a design and } \\
\text { innovation company }\end{array}$ & OpenIDEO Platform & $\begin{array}{l}\text { A global community } \\
\text { of professionals } \\
\text { interested in social } \\
\text { issues }\end{array}$ & $\begin{array}{l}\text { Solving difficult social } \\
\text { problems in areas such as } \\
\text { human rights, urbanization, } \\
\text { maternal health, and clean } \\
\text { water }\end{array}$ \\
\hline Ford Motor Company & The Ford StoryYour Ideas & $\begin{array}{l}\text { The brand's fan } \\
\text { communities, as well as } \\
\text { the University } \\
\text { of Michigan student } \\
\text { teams, among others }\end{array}$ & $\begin{array}{l}\text { Create social apps for the car } \\
\text { and support Ford in } \\
\text { modeling future versions } \\
\text { of Ford SYNC }\end{array}$ \\
\hline
\end{tabular}


Cont. table 3

\begin{tabular}{|c|c|c|c|}
\hline Company & Platform & Community & Benefits \\
\hline $\begin{array}{l}\text { Verizon, an American } \\
\text { telecommunications } \\
\text { company }\end{array}$ & Open Innovation Lab & $\begin{array}{l}\text { Telecommunications } \\
\text { device user communities } \\
\text { and start-ups }\end{array}$ & $\begin{array}{l}\text { Supporting each other in } \\
\text { solving technical problems. } \\
\text { The company's introduction } \\
\text { of a } 5 \mathrm{G} \text { mobile solution }\end{array}$ \\
\hline $\begin{array}{l}\text { One2tribe- mobile and } \\
\text { social games developer }\end{array}$ & One2tribe Platform & $\begin{array}{l}\text { Multiplayer game } \\
\text { communities }\end{array}$ & $\begin{array}{l}\text { Solutions for companies } \\
\text { such as Play, Empik, and } \\
\text { T-Mobile. Online and social } \\
\text { gaming market growth } \\
\text { of over } 40 \% \text { per year }\end{array}$ \\
\hline Procter \& Gamble Co & Connect \&Develop, & Consumer communities & $\begin{array}{l}\text { Lumi by Pampers, } \\
\text { a revolutionary and } \\
\text { integrated online care } \\
\text { system that combines } \\
\text { real-time data collected with } \\
\text { intuition to help parents } \\
\text { anticipate their baby's } \\
\text { needs }\end{array}$ \\
\hline Unilever & $\begin{array}{l}\text { Unilever Foundry IDEAS }{ }^{\mathrm{TM}} \\
\text { platform powered by Spigit }\end{array}$ & $\begin{array}{l}\text { Start-ups, creators, } \\
\text { and inventors around } \\
\text { the world }\end{array}$ & $\begin{array}{l}\text { Discovering innovative } \\
\text { solutions to meet the } \\
\text { challenges of sustainable } \\
\text { development }\end{array}$ \\
\hline
\end{tabular}

Source: Based on Boudreau and Lakhani, 2013; Rycharska, Kuczwalski, Stokalski, Ozimek, 2011 p. 107.

The main benefit of communities in creating innovations comes from finding solutions to the company's problems and gathering new knowledge and skills. This is possible thanks to sharing ideas by the open innovation project participants.

\section{Complementary communities}

An extremely valuable form of open innovation is communities' synergic activities, which, thanks to their creativity, enable them to solve many different problems by creating products complementary to the basic 
product. Platforms that allow generating such complementary innovations serve this purpose.

A good example is iTunes built around Apple's core mobile products the iPod, iPhone, and iPad. Through iTunes, vast groups of geographically dispersed developers create a wide range of complementary innovations, such as apps and podcasts created by users of these mobile devices.

The variety of complementary goods generates revenue and can also increase demand for the product itself, making it more useful. In turn, increased demand can increase the supply of complementary innovations and a whole host of network effects.

The effectiveness of using communities in creating complementary products is most significant for complex problems that require the consideration of a large number of diverse complements, which usually exceeds the internal potential and capabilities of a single company.

A fundamental prerequisite for the effective use of the community's potential in creating complementary products is to provide access to features and detailed information about the output product. The company, therefore, provides technology interfaces that allow external developers to participate in the creation of complementary innovations. If the core product is simple, then access to data sources from the website is sufficient. More complicated cases are cases in which participants in complementary communities must select core product features to create new solutions compatible with the lead product. For example, third-party developers must use application programming interfaces (APIs) to access the software vendor's capabilities to create complementary applications.

An excellent example of using institutional customers' potential to create innovations is Procter \& Gamble, which cooperates with young companies to acquire innovative approaches and new technological solutions. Fresh ideas and solutions are presented at Demo Day meetings organized by the company together with ABSL tech lab. The projects of such young technology companies as Brainly, Justtag, and Wise Shelf have shown Procter \& Gamble a new perspective that is a source of inspiration in creating a new approach to business processes. Through such collaborations, the company can create innovations for European and global customers in business analytics, marketing, supply chain planning, Business Intelligence, or Big Data (IT Innovations, 2020). These 
customized solutions allow them to build a competitive advantage and meet consumer expectations better.

Other companies also provide examples of success in open innovation. For example, Google in 2015 released its automated learning tool Tensorflow for collaboration under an open-source license (Appache 2.0). With Google's creation of third-party developers' ability to use the license, any solution they create that complies with the license terms can quickly evolve into a Google product. This strategy, typical in the IT industry, stimulates the company's growth, which has positioned itself as a significant player in artificial intelligence ( Pierrard, 2019 ).

Another example is Nestlé, the Swiss food giant who created an open innovation platform, "Henri @ Nestlé," through which it received more than 400 innovative solutions from start-ups in two years. The submissions received allow the company to respond to challenges in sustainability, nutrition, health, and consumer well-being (Nestlé, 2018).

\section{Gamification in the process of open innovation}

The main goal of gamification is to increase users' motivation to participate in a particular process by using techniques that create a game mechanism. Therefore, it is used to stimulate innovation activities in the organization, and it can be part of the innovation process. The impact of gamification on the area of innovation is multidimensional. Participation of the company's users and employees in a game stimulates free associations, divergent thinking, and creativity.

The use of gamification in the company's innovation process requires specific rules (Robra-Bissantz, Lattemann, 2017):

- customers should get to know the company and its objectives in order to acquire the knowledge needed to participate in innovation processes

- customers should act as part of the company and share the same values as its employees' values, especially when it comes to responsibility and loyalty

- customers should be creative and motivated and be willing to cooperate with other colleagues. 
Gamification allows deepening participants' positive motivation through incentives such as points earned, badges, prizes, feedback, and respect (Zichermann, Linder, 2010; Vassileva, 2012). The game scenario, which connects internal players with external players, includes teamwork based on a sense of belonging and mutual understanding. All players can formulate individual and group goals and decisions. The achievement of goals through the synergy effect leads to a common solution, revealing new approaches and interesting ideas along the way.

Thus, gamification components are used in the Customer Connection program implemented by SAP, allowing customers to directly influence products' continuous improvements within the company's development portfolio. Using gamification elements, the company increases customers' interest in participating in the program, proposing improvements in the offered products (Masser, Mory, 2018).

Customer-players operate on the Customer Influence platform acting in various roles: (1) "Submitters" who describe their ideas. (2) "Subscribers" who "vote" on an idea and thus prioritize it to make it eligible for analysis; (3) "Observers" who receive information about the progress of an idea and comment on it. The program uses key elements of gamification in order for its participants to have fun while working together to find the best solutions. These gamification features increase its usefulness in shaping the activity and involvement of participants in the innovation process.

\section{Factors determining the process of implementation of the open innovation model}

The effective use of customers' potential in creating innovation requires recognizing factors motivating customers to cooperate with the company and factors stimulating companies to engage customers in the innovation process.

When adopting the customers' perspective, it is necessary to consider psychological and behavioral processes that refer to the customers' motivation to cooperate with the company regarding innovation. Companies should perceive motivations and customer skills as necessary premises in managing innovation processes. Recognizing these motivations 
allows for creating appropriate ways to encourage customers to create innovation and effective customer input. Understanding customer motivation also facilitates selecting the right customers whose potential provides good prospects for cooperation with the company in creating innovations. Therefore, companies need to conduct marketing research focused on potential customers to recognize their characteristics, expectations, and willingness to cooperate with the company. There are a number of methods available. Their use requires an extremely valuable qualitative approach, which allows investigating the mechanism behind potential customers' motivation and needs and anticipating these needs and expectations. Monitoring trends and changes in the consumer behavior can be the starting point because it shows the space for searching for new product ideas.

When adopting the company's perspective, it is necessary to indicate the organization's internal factors that affect its approach to customer participation in creating innovations (Cui A, 2018). These are factors related both to the company's strategy and organizational aspects. They primarily concern managers' behaviors, their openness to cooperation with customers, and understanding of the benefits obtained from including customers in the process of creating innovations (Hoyer et al. 2010; Mohr and Sarin 2009, Bartl et al. 2012). Their decisions in managing the process of engaging customers also depend on managers' attitudes and role in building organizational culture.

The key is to recognize customer innovation's strategic impact on the innovation process and its implementation, such as creativity, efficiency, and speed. Furthermore, future research should identify how adopting an innovation model with customer participation can affect companies' overall strategic choices, management concepts, and long-term results.

Adopting a strategic perspective also requires consideration of customer innovation in the context of knowledge management processes. Customers play an active role in knowledge management if they have the opportunity to share knowledge and co-create a new product and innovative organizational or marketing solutions. However, such involvement requires treating customers as the company's crucial partners, who have a clear specificity compared to other stakeholders. Therefore, to effectively use their potential, new organizational structures and new management systems are needed. Directions of these changes are presented in Tab. 4. 


\section{Table 4. Directions of changes in management systems that support the implementation of a demand-driven approach to innovation}

\begin{tabular}{|c|c|c|}
\hline No. & Direction of changes & Characteristics and elements of changes \\
\hline 1. & New organizational culture & $\begin{array}{l}\text { Openness, tolerance, knowledge sharing as the key } \\
\text { values of organizational culture }\end{array}$ \\
\hline 2. & Changes in business models & $\begin{array}{l}\text { Introducing rules and solutions supporting broad } \\
\text { cooperation with the entities in the environment, } \\
\text { including customers - in the process of innovation creation }\end{array}$ \\
\hline 3. & $\begin{array}{l}\text { Changes in relationships between } \\
\text { company and customers }\end{array}$ & $\begin{array}{l}\text { Developing partnership relations with customers } \\
\text { through applying various forms and tools of cooperation } \\
\text { adjusted to the character and types of customers }\end{array}$ \\
\hline 4. & $\begin{array}{l}\text { Changes in the organizational } \\
\text { structure of the company }\end{array}$ & $\begin{array}{l}\text { The flexibility of the structure concerning changes occurring } \\
\text { in the environment and inclusion of customers in the process } \\
\text { of creating innovation }\end{array}$ \\
\hline 5 & $\begin{array}{l}\text { Intermediaries between the company } \\
\text { and entities in the environment in the } \\
\text { process of creation of open innovations }\end{array}$ & $\begin{array}{l}\text { The purpose of using their services is to reach external } \\
\text { entities, including end-users, more efficiently, thanks to } \\
\text { intermediaries' coordinating function and supporting } \\
\text { companies in acquiring creative customers. }\end{array}$ \\
\hline 6. & $\begin{array}{l}\text { Changes in staff management } \\
\text { of human resources }\end{array}$ & $\begin{array}{l}\text { The use of new methods of training the competencies of } \\
\text { managers and employees of various levels involved in building } \\
\text { relationships with customers }\end{array}$ \\
\hline 7. & $\begin{array}{l}\text { Shaping the system of communication } \\
\text { with customers }\end{array}$ & $\begin{array}{l}\text { Building efficient communication channels with the use } \\
\text { of forms and instruments dedicated to defined types } \\
\text { of customers }\end{array}$ \\
\hline 8. & Creating tools of cooperation with the customers & $\begin{array}{l}\text { Two groups of tools: - incentives for cooperation (tangible } \\
\text { and intangible) and techniques of customer creativity } \\
\text { stimulation-tools (platforms) for submitting innovations and } \\
\text { conducting the process simulations, running experiments, } \\
\text { and testing innovation with customers' participation }\end{array}$ \\
\hline 9. & $\begin{array}{l}\text { Integration of processes (products) designed } \\
\text { by the customer with internal NPD systems } \\
\text { (new product development) in the company }\end{array}$ & $\begin{array}{l}\text { Developing methods and principles for integrating these } \\
\text { processes }\end{array}$ \\
\hline 10. & Intellectual property management system & $\begin{array}{l}\text { Principles and forms of taking over the intellectual property } \\
\text { of customers - innovators }\end{array}$ \\
\hline
\end{tabular}

Source: own case study. 
Below we explain the changes needed to implement the demand-driven approach to innovation:

1. New corporate culture - the first stage of opening the company to using the open innovation model is transforming the organizational culture by saturating it with greater openness, tolerance, knowledge sharing, and the need to act jointly to pursue goals is. This leads to a change in mentality, which is the biggest barrier to introducing changes.

2. The company's business model — such a model should support extensive cooperation with different stakeholders, including customers, in the process of generating innovation. Focusing on a customer as an active participant in the innovation process requires defining the principles and forms of cooperation. Assumptions of the User design model, e.g., an open model of cooperation, require skillful customer knowledge management and efficient information flow between the company and its environment.

3. Shaping good relationships between the company and customers proper identification of customers by their interests in specific products, buying behaviors, and readiness to cooperate with the company should be the basis for these relationships. The company should develop partnership relationships with customers to motivate them to cooperate with the company. It also requires the use of various forms and tools tailored to the character and types of customers.

4. Shaping the communication system with customers - this system should be based on personalized communication channels with customers and forms and instruments of communication dedicated to recognized types of customers. This allows increasing the effectiveness of their influence on these customers.

5. Changes in the enterprise's organizational structure - developing cooperation with customers requires flexibility of the company's organizational structure and immediate response to the environment's signals. Hybrid organizational structures, e.g., matrix structures, which allow for the implementation of tasks beyond standard sets of tasks and employees' responsibility, can meet this challenge. Innovation centers in which customers and suppliers cooperate since the emergence of a new product can be an example of such structures. One such example is the case study of Mercadona, a leading retailer in Spain that introduces new products developed using this innovative approach to co-innovation (Albors - Garrigos, 2020). 
6. Intermediaries in the creation of open innovations - the new challenge is to use the services of new market actors acting as intermediaries in creating open innovations. Their mission is to support companies in opening themselves to cooperation with external entities, including consumers, in the best way. Intermediaries can adopt various forms and methods of operation, including network platforms, open innovative consultations, or performance of a cooperation accelerator's function by providing companies seeking innovation with solutions dedicated to them (AIbors-Garrigos, 2020). Using these intermediaries' services also allows companies to reduce the risk of cooperation with unknown entities and save time while searching for stakeholders willing to cooperate.

7. Changes in staff management - demand approach to innovation require proper preparation of the company employees at all management levels. It is important to apply new methods of training the competencies of managers and employees involved in shaping relationships with customers at various levels. Those skills should include skills needed to identify customers with creative potential who will cooperate with the company. Co-creation should not be seen as a threat to employees but rather as an encouragement to diversify thinking and recognize different views with customers' participation from many environments. Unilever cooperates within the Open Innovation Platform with individual customers and designers, researchers, or new companies (Unilever, access: 4/01/2018).

8. Creating Internet technology-based tools for cooperation with customers - in creating innovation, achieving the desired effects of cooperation with customers requires equipping them with appropriate tools, enabling the submission of ideas and other forms of participation in this process. The collaboration tools in innovation should be included in the enterprise's ERP (Enterprise Resource Planning) system. Such a system allows for the integration of organizational processes. Therefore, in addition to all management functions included in the system and related to production, finance, sales, or marketing, among others, the new area of open innovations should be added. Within this function, it is necessary to add crowdsourcing platforms for reporting innovations, create models of process simulations, conduct experiments, and test innovations (products, solutions) with customer participation. Cooperation with customers may also require the use of a variety of techniques to stimulate customer creativity. 
9. Integration of the processes of customer participation with internal NPD systems (new product development and production systems) Achieving integration of open innovation processes with existing NPD systems is a serious challenge for companies (Cui, 2018). This integration is necessary to ensure the elementary conditions for implementing innovation.

10. Development of a strategy for managing the intellectual property system

The application of customer potential-based concepts requires the company to solve legal problems related to copyright. Acquiring intellectual property is complex and involves many challenges because a high level of intellectual property protection inhibits open innovations. The lack of such protection can lead companies to hide new company solutions, which hinders but even restrains the development of open innovations. Therefore, it is necessary to establish clear and detailed rules for intellectual property management strategy, as the lack of caution and violation of these principles can have profound legal implications. First of all, the acquiring company should ensure that the purchased intellectual property enjoys balanced legal protection under one of the categories of intellectual property rights recognized by law (Mention, Al-Sharieh, 2013).

The use of intellectual property in open, innovative environments may take the form of attribution/acquisition of intellectual property and intellectual property license. Both forms are legal actions that must be effectively applied to avoid negative consequences from the legal protection of companies' intellectual property involved in open innovations.

It should be noticed that intellectual property licensing resolves the tension between knowledge protection and knowledge sharing (Bogers, 2011). Based on a survey conducted among over 154 industrial companies, Lichtenthaler (2010) observed that intellectual property portfolio size plays a vital role in encouraging the company to move to the open innovation paradigm.

The best approach that enables proper use of the intellectual property right to stimulate innovation is to design it so that the right balance between external innovators' and the company's interests is achieved.

The possible solutions include co-patenting by the entities involved in the cooperation and applying for the legal protection of jointly owned inventions. However, there is a risk of a conflict of interest between the patent co-owners (Wściubiak, 2017). 
When assessing the effects of consumer participation in the process of value creation, especially the creation of innovations, the following impact on the company, economy, and society should be emphasized:

- Increasing the role of human capital in business models and the scale of social participation in management;

- Gaining access to non-standard concepts through acquiring knowledge directly from the market and strengthening relationships with customers;

- Transforming the organizational business innovation system through opening it to external stakeholders;

- Increasing the efficiency of operations related to the creation of innovations. The achieved results prove to be valuable concerning the relatively small costs of cooperation with customers;

- Increasing the chance of satisfying consumer needs in accordance with individual aspirations and expectations as well as possibilities of selfrealization of consumers - innovators;

- Stimulating social entrepreneurship development, development of a partnership network, culture of trust, and cooperation.

However, it is also necessary to indicate the possible destructive impact of customer-organization value creation practices. This is a phenomenon of the so-called co-destruction that may result from the inappropriate or unexpected use of resources, e.g., inconsistent with the resource provider or potential user's perspective. This can be accidental or intentional. Accidental improper use may result from the lack of sufficient customer knowledge. As Jeff Howe said, "sometimes the crowd can be wise, but sometimes it can also be stupid" (Surowiecki, 2019).

Deliberate abuse resulting from sabotage or opportunistic behavior can be a threat. Dziewanowska (2017) and Harris LC and Ogbonna E. (2006), as well as DA Greer (2015), describe three types of defective behaviors, including relational (e.g., insufficient or excessive participation), interpersonal (e.g., verbal or physical), and inappropriate behaviors (property abuse and fraud).

It should also be emphasized that thanks to the progress in Internet technologies and the growing popularity of social media, crowdsourcing offers new forms of work. Simultaneously, the question arises whether these new forms of work allow employees to create their careers or create a workshop where employees perform fragmented tasks to earn a minimum wage (Howe, 2006). 
There are a few threats to the organization-customer value co-creation:

- Ethical issues related to injustice, lack of transparency and clearly defined fair rules, or non-compliance with previously established rules for customer participation in the value creation process;

- Difficulties in maintaining the confidentiality of information, which may lead to cooperation only with contractors cooperating in a long term;

- Risk arises from manipulating crowdsourcing participants through stronger, more opinion-forming individuals and a leader that does not necessarily support the initiative (Surowiecki, 2019).

\section{Conclusions}

Co-creation of value with customers' active role is a big challenge. The customer is no longer just the recipient of the offer but increasingly becomes a co-creator of organizational value or even contributes as an innovator. The development of information and communication technologies means that the customer's cooperation with the company takes various forms, among which joining the creation of open innovations is crucial. Effective use of customer potential requires recognizing both factors motivating customers to cooperate with the company and factors stimulating companies to engage customers in the innovation process. This allows the development of an appropriate model for managing the innovation process with customers' active participation. The application of such a model has specific strategic implications regarding organizational culture, business models, and changes in company management systems, especially in internal and customer-centric knowledge management. Cultural changes resulting in the growing importance of such values as taking initiatives, creativity, self-realization, and striving to participate in shaping reality are important in developing open innovation. Achieving effects for both end-users and the organization will result from the impact of stimulants and destimulants of value creation with the participation of users. The effectiveness of using factors supporting open innovation and minimizing the impact of various types of threats depends on managers' experience and skills. 


\section{References}

1. AIbors - Garrigos, J. and de Miguel Molina, M. (2020). Integrating Customers and Suppliers in Retail Co-innovation. Journal Research - Technology Management, 63(3).

2. Balaji, M. and Roy, S. (2017). Value co-creation with internet of things technology in the retail industry. Journal of Marketing Management, Vol. 33 Nos 1/2, 7-31.

3. Baran, M., Ostrowska, A. and Pander, W. (2012). Innowacje popytowe, czyli jak tworzy się wspótczesne innowacje. Warszawa: Polska Agencja Rozwoju Przedsiębiorczości.

4. Bartl, M., Füller, J., Mühlbacher, H. and Ernst, H. (2012). A manager's perspective on virtual customer integration for new product development. Journal of Product Innovation Management, 29(6), 1031-1046.

5. Bogers, M. (2011). The open innovation paradox: Knowledge sharing and protection in R\&D collaborations. European Journal of Innovation Management, 14(1), 93-117.

6. Boudreau, K. J. and Lakhani, K. R. (2013). Using the Crowd as an Innovation Partner $H B R$. www.hbr.org

7. Busse, M. and Siebert, R. (2018). The role of consumers in food innovation processes. European Journal of Innovation Management, 21(1).

8. Chepurna, M. and Criado, J. R. (2018). Identification of barriers to co-create online: the perspectives of customers and companies. Journal of Research in Interactive Marketing, 12(4), 452-471 Emerald Publishing.

9. Chesbrough, H. (2003). Open Innovation: The New Imperative for Creating and Profiting from Technology Boston. Harvard Business School Press.

10. Cui, A. (2018). Customer Involvement in Innovation: A Review of Literature and Future Research Directions 2018. Review of Marketing Research, July 2018.

11. Dobiegała-Korona, B. (2010). Strategie innowacji w budowie kapitału klienta. W: Zarzadzanie wartościa klienta. Pomiar i strategie, red. nauk. B. Dobiegała-Korona, T. Doligalski. Warszawa.

12. Dziewanowska, K. (2017). Współtworzenie i współniszczenie wartości, czyli wady i zalety współpracy z klientem. Studia Ekonomiczne. Zeszyty Naukowe UE w Katowicach, 328.

13. Greer, D.A. (2015). Defective co-creation. European Journal of Marketing, 49(1/2), 238-261.

14. Gummesson, E. and Mele, C. (2010). Marketing as value co-creation through network interaction and resource integration. Journal of Business Market Management, 4(4), 181-198.

15. Harris, L.C. and Ogbonna, E. (2006). Service Sabotage: A Study of Antecedents and Consequences. Journal of the Academy of Marketing Science, 34(4), 543-558.

16. Hoyer, W. D., Chandy, R., Dorotic, M., Krafft, M. and Singh, S. S. (2010). Consumer cocreation in new product development. Journal of Service Research, 13(3), 283-296.

17. Howe, J. ( 2006), Rise of the crowdsourcing. Wired magazine, 14(6) 1-4.

18. Innowacje IT, (2020). Innowacje $w$ obszarze IT zaczynaja się od konsumentów. www.money.pl (11.12.2020).

19. Kieżel, M. and Wiechoczek, J. (2016). Zaangażowanie klienta (ce) w sektorze dóbr zaawansowanych technicznie oraz sektorze bankowym. Studia i Prace WNEIIZ US, 434/2.

20. Lakhani, K. R. and Wolf, R. G. (2003). Why Hackers Do What They Do: Understanding Motivation and Effort in Free/Open Source Software Projects. Electronic Journal Unfollow journal. DOI: 10.2139/ssrn.443040

21. Lichtenthaler, U. (2010). Intellectual property and open innovation: An empirical analysis. International Journal of Technology Management, 52(3/4), 372-391. 
22. Liu, Q., Zhao, X. and Sun, B. (2018). Value co-creation mechanisms of enterprises and users under crowdsource-based open innovation. International Journal of Crowd Science, 2(1).

23. Malinowski, B. F. (2018). Czym jest crowdsourcing. www.wethecrowd.pl (21.04.2019).

24. Masser, K. and Mory, L. Gamification-Engaging People by Letting Them Have Fun. www.link.springer.com

25. Mazurek-Łopacińska, K. (2013). Klient w kreowaniu innowacji na współczesnym rynku: modele, narzędzia, przykłady. Handel Wewnętrzny, 1-2.

26.Mazurek-Łopacińska, K. (2012). The Customer in Creating Innovation - Challenge for the Enterprise. W: Olejniczuk-Merta A. (red.), The Transformation of Consumption and Consumer Behaviour. Warszawa: IBRKK.

27. Mention, A.-L. and Al-Sharieh, S. ( 2013). Open Innovation and Intellectual Property: The Relationship and Its Challenges, www.researchgate.net (15.05.2020).

28. Mierzejewska, B. (2008). Open innovation - nowe podejście w procesach innowacji. E-Mentor, 2(24).

29. Milewski, F. (2015) (red.). Ttum jako źródto wiedzy i kapitału. PARP.

30. Mohr, J. J. and Sarin, S. (2009). Drucker's insights on market orientation and innovation: implications for emerging areas in high-technology marketing. Journal of the Academy of Marketing Science, 37, 85-96.

31. Nestlé's Open Innovation Platform Celebrates Two Years Of Creative Solutions Jun 26 2018 3:00. www.esmagazine.com (7.11.2019).

32. Norton, K., (2019). 12 Brands Using Crowdsourcing for Product Design Ideas, www.cadcrowd.com (21.12.2020)

33. Ohori, K. and Takahashi, S. (2007). Agent-based Analysis of Lead User Innovation in Consumer Product Market. W: Agent - Based Approaches in Economic and Social Complex, vol. 6, Springer vol. 6, 267-279.

34. Pierrard, S. (2019). Innovation ouverte: vers de nouveaux modeles de propriété intellectuelle? www.lavery.ca (15.12.2020).

35. Raport Nordic Innovation Center. (2010), 21.

36. Robra-Bissantz, S. and Lattemann, Ch. (2017). Customer-Oriented Strategies and Gamification-The Example of Open Customer Innovation. W: Stieglitz S., Lattemann Ch., Robra-Bissantz, S., Zarnekow, R. and Brockmann, T., Gamification. Using Game Elements in Serious Contexts. Springer.

37. Rossi, M. V. and Magni, D. (2017). Investigating Intellectual Capital Role inValue Co Creation lectual Capital. Journal of Marketing, 1.

38. Rycharska M., Kuczwalski R., Stokalski B. and Ozimek, W. (2011). Gra o klienta czy gra z klientem? Nowa generacja usług elektronicznych. W: Gotowi na innowacje. Warszawa: Infovide-Matrix.

39. Sopińska, A. (2013). Otwarte innowacje bazujące na mądrości „tłumu” — podstawa sukcesu współczesnego przedsiębiorstwa. Zarzadzanie i Finanse, 11(4). Uniwersytet Gdański.

40. Surowiecki, Korzyści i zagrożenia crowdsourcingu. www.nf.pl (11.04.2019).

41. Szopik-Depczyńska, K. (2018). Koncepcja innowacji kreowanej przez użytkownika $w$ działalności badawczo-rozwojowej. Wydawnictwo Naukowe Uniwersytetu Szczecińskiego.

42. Tapscott, D. and Williams, A. D., (2011). Makrowikinomia. Reset świata i biznesu. Warszawa: Wydawnictwo Studio Emka.

43. Vassileva, J. (2012). Motivating participation in social computing applications: A user modeling perspective. User Modeling and User-Adapted Interaction, 22(1-2), 177-201. 
44. Von Hippel, E. (2005). Democratizing Innovation. The MIT Press Cambridge. London: Massachusetts. https://oi.org/10.7551/mitpress/2333.001.0001

45. Wojnicka, E. (2011). Popytowe podejście do innowacji - charakterystyka koncepcji. PARP.

46. Wściubiak, Ł. (2017). Rola praw własności intelektualnej w świetle koncepcji otwartych innowacji. Studia i Prace WNEIZ US, 48/3.

47. www.mystarbucksidea.force.com (15.12.2020).

48. www.unilever.com/about/innovation/open-innovation/ (4.01.2019).

49. Zichermann, G. and Linder, J. (2010). Game-based marketing: inspire customer loyalty through rewards, challenges, and contests. New Jersey: Wiley.

Krystyna Mazurek-Łopacińska, Professor, The Wroclaw University of Economics and Business, Poland - Professor of Economic Sciences, Head of the Marketing Research Department of The Wroclaw University of Economics and Business (since 1994), Deputy Rector for Didactics at the WUE (in the years 2002-2005) and Head of the Marketing Institute (2011-2016). She served Her internships at the University of Lille, International Business School in Marseilleand at the Paris-Evry University. One of the leading Polish specialists in the sphere of marketing research and economics of consumption, as well as consumer market behavior. Her scientific and research interests concern marketing strategies, customer orientation in the enterprise, intercultural marketing communication, marketing in the culture sphere. Her scientific achievements include over 300 published items (monographies, textbooks and articles), among them are Her books concerning the Consumer Behavior which were awarded with the Prizes of the Minister of Higher Education: „Purchasers' Behavior as the Basis of the Marketing Strategy”, Wydawnictwo Uniwersytetu Ekonomicznego we Wroctawiu 1996 (Publishing House of the University of Economics in Wroctaw), and „Purchasers' Behavior and Its Marketing Consequences", Polskie Wydawnictwo Ekonomiczne 2003 (Polish Economics Publishing House). She is an editor and co-author of 16 monographies i Scientific Works dedicated to the methodology issue and implementation of the marketing research, as well as textbooks, the last one - „Marketing Research. Methods, Techniques and Areas of Application in The Modern Market" was published in 2016 by Polskie Wydawnictwo Naukowe (Polish Scientific Publishing House). She is a co-author of the monography "Marketing in the Digital Technologies Era. Modern Conceptions and Challenges" published by PWN in 2018. A third-party examiner at the Nottingham Trent University (2007-2013) and the Chairwoman of the Accreditation Commission of the Foundation for the Promotion and Accreditation of Economic Education (2005-2016). She is a member of the Committee on Organizational and Management Sciences of the Polish Academy of Sciences (2015-2020). As a recognized expert she was a member of the Permanent Team of the National Science Centre (2012-2015). She also is a member of the Reseau des Pays du Groupe de Vysegrad Association. 